\title{
GOSPODAROWANIE ODPADAMI MEDYCZNYMI I WETERYNARYJNYMI W USTAWIE O ODPADACH
}

\section{MEDICAL AND VETERINARY WASTE MANAGEMENT IN THE ACT ON WASTE}

\section{STRESZCZENIE}

Celem artykułu jest przedstawienie regulacji związanych z gospodarowaniem odpadami medycznymi i weterynaryjnymi, zawartych $\mathrm{w}$ ustawie o odpadach. Wskazane typy odpadów, ze względu na szczególny sposób pochodzenia i swoje właściwości (np. „niebezpieczne” czy „zakaźne”) mogą stanowić istotne zagrożenie zarówno dla człowieka, jak i środowiska. Z tego powodu wszelkie działania z nimi związane podlegają często odrębnym i zaostrzonym, w stosunku do reguł ogólnych, reżimom postępowania. Niniejsza praca zawiera kompleksową analizę najważniejszych źródeł prawa dotyczących zagospodarowania odpadów medycznych i weterynaryjnych oraz cha-

\footnotetext{
Magister prawa.
} 
rakteryzuje poszczególne ich podgrupy. Ponadto artykuł prezentuje dopuszczalne metody unieszkodliwiania takich odpadów.

\section{Słowa kluczowe}

Odpady medyczne; odpady weterynaryjne; gospodarowanie odpadami; odpady niebezpieczne i zakaźne.

\section{ABSTRACT}

The aim of this article is to present regulations concerning the management of medical and veterinary waste in the Act on Waste. These types of waste because of their place of origin and properties (e.g. 'dangerous' or 'infectious') may pose a significant peril both to people and the environment. For this reason, all activities associated with such waste are often subject to a separate and more rigorous regimes of proceedings, in relation to general rules. This paper contains a comprehensive analysis of major sources of law relating to medical and veterinary waste management and also characterises individual subgroups of described waste. Furthermore, the article presents the most important and most common methods of disposal of such waste allowed by law.

\section{Keywords}

Medical waste; veterinary waste; dangerous and infectious waste; waste management; environmental law.

\section{WSTĘP}

Odpady nie stanowią elementów przyrody, a zatem nie są częścią środowiska naturalnego. Jednakże ze względu na swoje szkodliwe właściwości, stwarzają dla niego poważne zagrożenie, gdyż środowisko tylko w nieznacznym zakresie jest zdolne do ponoszenia obciążeń antropogenicznych. Prawidłowe zagospodarowanie odpadów jest konieczne i ma doniosły wymiar społeczny. To dlatego właśnie są one istotnym przedmiotem zainteresowania prawa ochrony środowiska. 
Odpady medyczne i weterynaryjne ze względu na swój charakter oraz szczególny sposób pochodzenia bez wątpienia należy uznać za odrębne i specyficzne kategorie odpadów, które powinny być objęte specjalnymi regulacjami normatywnymi w dziedzinie kontroli i gospodarowania.

W Polsce rocznie powstaje około 200 tys. ton takich odpadów, a około $15 \%$ z nich stanowią odpady zakaźne ${ }^{1}$ cechujące się obecnością bakterii, toksyn, grzybów lub chemikaliów. Odpady weterynaryjne stanowią około 10\% sumy odpadów medycznych i weterynaryjnych ${ }^{2}$. Odpady zakaźne stwarzają poważne zagrożenie biologiczne (epidemiologiczne) zarówno dla środowiska, jak i zdrowia oraz życia ludzi. Według prognozy na lata 2003-2014 sporządzonej na podstawie danych statystycznych (prognoza demograficzna, dynamika wzrostu PKB), zawartych w literaturze przedmiotu oraz doświadczenia właściwych służb, liczba zakaźnych odpadów medycznych stale rośnie, od 25,8 tys. ton w 2003 r. do 29 tys. ton w 2014 r. $^{3}$

Raport Najwyższej Izby Kontroli dotyczący gospodarki odpadami medycznymi w latach 2003-2006, w sposób negatywny ocenił przedmiotowe działania, jednakże podkreślić należy, iż wskazana sytuacja miała miejsce pod rządami uchylonych już aktów prawnych regulujących tę materię .

Ponieważ omawiane typy odpadów różnią się szkodliwością, to ustawa $\mathrm{z}$ dnia 14 grudnia 2012 r. o odpadach ${ }^{5}$ wprowadza oprócz ogólnych kategorii odpadów medycznych i weterynaryjnych oraz kategorii odpadów niebezpiecznych,

1 K. Forowicz, Odpady Szpitalne - bać się czy nie?, „Odpady i Środowisko” 2012, nr 1, s. 65.

2 Baza danych wybranych metod i urządzeń do utylizacji odpadów [online], dostęp: 12.02.2014, <http://zasoby1.open.agh.edu.pl/dydaktyka/inzynieria_srodowiska/c_utylizacja_odpadow/index1.php?menu=04\&domenu$=04 / 02 \&$ nrPorzadkowy $=09 \&$ strona $=0 \& w c z y t a j=$ odpady_niebezp/odzysk unieszk/medyczne_weteryn/info.htm\&podMenu $=\mathrm{T}>$.

3 Ibidem.

4 Najwyższa Izba Kontroli, Departament Środowiska, Rolnictwa i Zagospodarowania Przestrzennego, Informacja o wynikach kontroli postępowania z odpadami medycznymi, Warszawa 2007.

${ }_{5}$ Tj. Dz.U. z 2013 r., poz. 21, dalej cyt.: u. o. 
podkategorie w obrębie których wyszczególnia zakaźne odpady medyczne oraz zakaźne odpady weterynaryjne.

\section{ZAKRES REGULACJI ORAZ ZASADY OGÓLNE USTAWY O ODPADACH}

Zgodnie z art. 1 u.o. określa ona środki służące ochronie środowiska, życia i zdrowia ludzi zapobiegające i zmniejszające negatywny wpływ na środowisko oraz zdrowie ludzi wynikający z wytwarzania odpadów i gospodarowania nimi. Ponadto ustawa ta reguluje również użytkowanie zasobami (ograniczanie skutków ogólnego użytkowania, poprawienie efektywności).

Definicja normatywna zawarta w art. 3 ust 1 pkt 6 u.o. uznaje za odpady każdą substancję lub przedmiot, których posiadacz pozbywa się, zamierza się pozbyć lub do których pozbycia się jest obowiązany. W konsekwencji tego, aby uznać daną substancję (przedmiot) za odpad, konieczne jest wystąpienie elementu „pozbycia się" czy to w wyniku faktycznego działania (ad casum zaniechania), posiadania woli i zamiaru dokonania takiej czynności bądź zobowiązania do jej dokonania6. W. Radecki wskazuje, iż powyższa „triada” służąca definiowaniu pojęcia „odpady” jest od dawna znana zarówno w prawie polskim, jak i unijnym ${ }^{7}$. Podkreślić również należy, że wystarczy spełnienie tylko jednego z jej elementów. Do określenia, czy dana substancja (przedmiot) jest odpadem zobowiązany jest wytwórca (posiadacz), jednakże jego ocena może być przedmiotem weryfikacji przez odpowiednie organy kontroli. Wskazać trzeba zatem, że ustawowa definicja uwzględnia pożądany stopień arbitralności w kwestii uznania substancji (przedmiotu) za odpad. Definicja pojęcia „odpad” jest zbieżna z definicją zawartą w dyrektywie 2008/98/WE ${ }^{8}$. s. 44.

A. Pacek-Łopalewska, Ustawa o odpadach. Komentarz, Wrocław 2013,

W. Radecki, Ustawa o odpadach. Komentarz, Warszawa 2013, s. 103.

8 Dz.Urz. UE L 312 z 22.11. 2008, s. 9. 
Ustawa o odpadach znajduje zastosowanie do wszystkich rodzajów odpadów w tym m.in. odpadów komunalnych, odpadów zielonych, bioodpadów, olejów opałowych, odpadów medycznych i weterynaryjnych oraz odpadów PCB, chyba że podlegają one wyłączeniu, które dotyczy m.in. gazów i pyłów wprowadzanych do atmosfery, odpadów promieniotwórczych, ścieków bądź niektórych rodzajów biomasy.

Pojęcie gospodarowania odpadami jest bardzo szerokie i kompleksowe. Obejmuje ono czynności zbierania, transportu, przetwarzania odpadów, nadzór nad takimi działaniami, a także późniejsze postępowanie z miejscami unieszkodliwiania odpadów oraz działania wykonywane $\mathrm{w}$ charakterze sprzedawcy odpadów lub pośrednika w ich obrocie. W literaturze przedmiotu słusznie wskazuje się, że zasady gospodarowania odpadami dostrzegalne są już na poziomie prewencjị. R. Paczuski analizując termin „gospodarowanie odpadami”, zwraca uwagę, iż nie tylko powinien być on odnoszony do aspektu sanitarnego (przyczynianie się do ochrony zdrowia ludzkiego oraz do zachowania i poprawy jakości środowiska), ale także do aspektu gospodarczego, tj. walki z marnotrawstwem zasobów ${ }^{10}$.

Wytwórcą odpadów jest każdy, którego działalność lub bytowanie powoduje powstanie odpadów (tzw. wytwórca pierwotny) oraz każdy, kto przeprowadza wstępną obróbkę, mieszanie lub inne działanie powodujące zmianę charakteru lub składu tych odpadów. Z kolei posiadaczem odpadów jest wytwórca odpadów lub osoba fizyczna, osoba prawna oraz jednostka nieposiadająca osobowości prawnej będąca w posiadaniu odpadów.

Dział II ustawy o odpadach określa katalog zasad ogólnych gospodarki odpadami. Powinna być ona prowadzona w sposób zapewniający ochronę życia i zdrowia ludzi oraz środowiska i nie może powodować zagrożenia dla wody, powietrza, gleby, roślin lub zwierząt, powodować uciążliwości przez hałas lub zapach, a także wpływać w sposób niekorzystny na tereny wiejskie lub miejsca o szczególnym znaczeniu. Artykuł 17 u.o.,

9 B. Wierzbowski, B. Rakoczy, Prawo ochrony środowiska. Zagadnienia podstawowe, Warszawa 2012, s. 271.

10 R. Paczuski, Prawo ochrony środowiska, Bydgoszcz 2000, s. 352. 
wprowadza pożądaną hierarchię sposobów postępowania z odpadami polegającą, w pierwszej kolejności, na zapobieganiu ich powstawania, następnie przygotowywaniu do ponownego użycia, recyklingu lub innych procesach odzysku, kończąc zaś na unieszkodliwianiu. Norma ta priorytetowo odnosi się do działań mających na celu zapobieganie powstawaniu odpadów, stanowiąc ponadto wyraz promowanej na poziomie europejskim

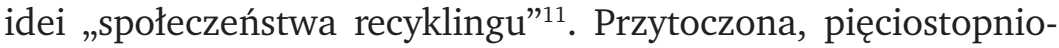
wa hierarchia jest zgodna z tą, którą zawarto w dyrektywie 2008/98/WE.

Istotna jest również zasada bliskości zawarta w art. 20 u.o., zgodnie z którą odpady powinny być przetwarzane $\mathrm{w}$ miejscu ich powstania, a gdy warunek ten nie może być spełniony, w najbliższym odpowiednim dla tego celu miejscu. Omówione regulacje są w dużej mierze zbieżne z zasadami określającymi strategię gospodarowania odpadami w Unii Europejskiej. Artykuł 20 u.o. stanowi implementację art. 16 dyrektywy 2008/98/ WE, jednakże polski ustawodawca nie nawiązał w nim do zasady samowystarczalności, która sformułowana została w art. 16 tej dyrektywy. Nakazuje ona tworzenie zintegrowanej i wystarczającej sieci instalacji do unieszkodliwiania odpadów i instalacji do odzysku zmieszanych odpadów komunalnych zebranych z gospodarstw domowych. Zasada samowystarczalności jest powiązana z zasadą bliskości w ten sposób, iż ma służyć zminimalizowaniu liczby przypadków, które stanowią wyjątki od zasady bliskości ${ }^{12}$.

Zasada bliskości zawarta w art. 20 u.o. rozpatrywana jest tylko w aspekcie wewnętrznym. W aspekcie zewnętrznym powinna być rozpatrywana zwłaszcza w świetle ${ }^{13}$ : Konwencji bazylejskiej o kontroli transgranicznego przemieszczania i usuwania odpadów niebezpiecznych ${ }^{14}$, decyzji Rady OECD C(2001)107/FINAL

11 Zob. M. Wladarz, Gospodarka odpadami. Poradnik przedsiębiorcy, Warszawa 2003, s. 13-20.

12 K. Karpus, [w:] Ustawa o odpadach. Komentarz, B. Rakoczy (red.), Warszawa 2013, s. 71.

13 Ibidem, s. 72-76.

14 Dz.U. z 1995 r. Nr 19, poz. 88. 
ustanawiającej ramy dla państw członkowskich OECD w sprawie kontroli transgranicznego przemieszczania odpadów przeznaczonych do odzysku na obszarze $\mathrm{OECD}^{15}$ oraz rozporządzenia (WE) nr 1013/2006 Parlamentu Europejskiego i Rady z 14 czerwca 2006 r. w sprawie przemieszczania odpadów ${ }^{16}$.

\section{DEFINICJA I KLASYFIKACJE ODPADÓW MEDYCZNYCH I WETERYNARYJNYCH}

Zgodnie z definicją zawartą w art. 3 ust. 1 pkt 8 u.o., przez pojęcie odpadów medycznych rozumie się odpady powstające w związku z udzielaniem świadczeń zdrowotnych oraz prowadzeniem badań i doświadczeń naukowych w zakresie medycyny. Normatywne zakreślenie granic analizowanego terminu jest bardzo szerokie, co należy uznać za rozwiązanie właściwe, bowiem kryterium decydującym o uznaniu substancji (niezależnie od stanu skupienia tj. stanu stałego, ciekłego bądź gazowego) lub przedmiotu za odpad medyczny jest ich związek z określonymi czynnościami. Zapewnia to pożądaną elastyczność regulacji, jednakże mogącą prowadzić do konieczności stosowania skomplikowanych i drogich metod utylizacji odpadów, które tego nie wymagają. Jest to "efekt uboczny” koniecznych rozwiązań normatywnych. O ile pojęcia prowadzenia badań i doświadczeń naukowych w zakresie medycyny są oczywiste, o tyle przez udzielanie świadczenia zdrowotnego należy rozumieć pojedynczą czynność lub zespól czynności stosowanych w Systemie Opieki Zdrowotnej, mających na celu zmianę stanu zdrowia, co najmniej do poziomu uznanego w danej społeczności za prawidłowy ${ }^{17}$. Przedmiotowa definicja powstała na potrzeby prawa medycznego, niemniej stanowi istotną wskazówkę dla wykładni

15 OECD Decision C(2001)107/FINAL [online], dostęp: 14.02.2014, <http://www2.oecd.org/waste/>.

16 Dz.Urz. UE L 190 z 12.07.2006 ze zm.

17 Ogólnopolski System Ochrony Zdrowia [online], dostęp: 10.02.2014, <https://www.osoz.pl/osoz/web/osoz-cms/definicje>. 
analizowanego terminu. Podkreślić jednak należy, iż na gruncie ustawy o odpadach, pojęcie świadczenia zdrowotnego jest szersze i obejmuje nie tylko czynności mające charakter leczniczy w ścisłym znaczeniu, ale również działania diagnostyczne oraz profilaktyczne ${ }^{18}$ podejmowane $\mathrm{w}$ obiektach lecznictwa zamkniętego i otwartego. Dla właściwego zdefiniowania odpadów medycznych konieczne jest także wskazanie podmiotów, u których one powstają - tzw. wytwórców. Są to różne jednostki opieki zdrowotnej tj. szpitale ogólne, szpitale psychiatryczne, szpitale uzdrowiskowe, sanatoria rehabilitacyjne, ośrodki leczenia odwykowego, zakłady pielęgnacyjno-opiekuńcze, zakłady leczniczo-wychowawcze, zakłady opiekuńczo-lecznicze, sanatoria uzdrowiskowe, ośrodki zdrowia, przychodnie, poradnie, punkty lekarskie, hospicja oraz praktyki lekarskie (indywidualne, indywidualne specjalistyczne i grupowe).

Wśród odpadów medycznych, zgodnie z wytycznymi Głównego Inspektora Sanitarnego wyróżnia się cztery grupy, z których tylko te sklasyfikowane jako bytowo-gospodarcze nie stwarzają zagrożenia dla środowiska. Podział prezentuje się następująco:

- „odpady bytowo-gospodarcze” (np. pochodzące z pomieszczeń biurowych, zaplecza warsztatowego, oddziałów niezabiegowych oraz odpady z kuchni i resztki posiłków z oddziałów niezakaźnych). Tworzą one przeważającą część odpadów powstałych w placówkach służby zdrowia (około 75 - 90\%). Odpady te nie stanowiąc (istotnych) zagrożeń biologicznych lub chemicznych nie wymagają zabiegów dezynfekcyjnych poprzedzających ich recykling lub utylizacje, przez co powinny być traktowane jako odpady powstałe w gospodarstwie domowym ${ }^{19}$,

- „odpady infekcyjne (specyficzne)”, które ze względu na bezpośredni kontakt z chorymi stanowią zagrożenie infekcyjne dla ludzi i środowiska. Czynnikiem wyróżniają-

18 Rozporządzenie Ministra Środowiska z dnia 27 września 2001 r. w sprawie katalogu odpadów, Dz.U. z 2001 r. Nr 112, poz. 1206.

19 M. Kowalska, Praktyczna klasyfikacja odpadów powstających $w$ placówkach stużby zdrowia. Gospodarka odpadami medycznymi, Kraków 2002, s. 42. 
cym tę kategorię jest zawartość drobnoustrojów chorobotwórczych tj. wirusów, bakterii czy pasożytów w ilości wystarczającej do wywołania zakażenia. Często zdarza się, że odpady pochodzące bezpośrednio ze szpitali i uznane za infekcyjne zawierają dużo mniej patogenów niż odpady komunalne $\mathrm{z}$ uwagi na fakt używania tam substancji dezynfekujących. Ponadto, wbrew powszechnym opiniom, odpady komunalne zawierają również znaczą ilość krwi²0. Według WHO od 10 do 25\% ogólnej masy wszystkich odpadów medycznych stanowią odpady infekcyjne. Z kolei Amerykańska Agencja Ochrony Środowiska (US EPA) wskazuje, iż jest to od 10 do 15\% łącznej masy odpadów. Do odpadów zakaźnych zalicza się m.in. ${ }^{21}$ zanieczyszczone ostre przedmioty, igły, płytki szklane, krew i odpady zanieczyszczone krwią, wydalinami, wydzielinami i płytkami tkankowymi chorych, zanieczyszczone materiały opatrunkowe czy szczątki i ściółka zwierząt laboratoryjnych, jeżeli pozostawały w kontakcie z czynnikiem infekcyjnym,

- „odpady specjalne” czyli niebezpieczne substancje i preparaty stosowane w ośrodkach medycznych, niekoniecznie związane z działaniami leczniczymi, ale również będące np. zwykłym wyposażeniem budynków. Do tej grupy kwalifikuje się m.in. substancje radioaktywne, uszkodzone termometry rtęciowe, zużyte świetlówki, akumulatory (np. od sanitarki) substancje toksyczne i odpady srebronośne,

- „odpady patologiczne i anatomiczne”, tj. rozpoznawalne szczątki ludzkie (części ciała, organy, odpady poporodowe, posekcyjne i pooperacyjne oraz ciała martwo urodzonych noworodków. Jest to mniej niż $2 \%$ ogólnej masy odpadów medycznych ${ }^{22}$.

20 H. Wyrębek, Zarządzanie gospodarką odpadami medycznymi w Polsce, „Zeszyty Naukowe Uniwersytetu Przyrodniczo - Humanistycznego w Siedlcach. Seria: Administracja i Zarządzanie" 2010, nr 87, s. 118.

21 M. Kowalska, op. cit., s. 43.

22 H. Wyrębek, op. cit., s. 119. 
Ponadto można wyróżnić jeszcze odpady powstałe w wyniku termalnej przeróbki odpadów specyficznych (np. popiół czy zeszklony żużel).

Odpady infekcyjne powinny być gromadzone selektywnie, ponieważ wymagają unieszkodliwiania na drodze termicznego przekształcania, natomiast odpady specjalne wymagają odrębnych, właściwych, dla danego materiału, technik utylizacji, które są niezbędne ze względu na ich chemiczną i fizyczną charakterystykę ${ }^{23}$.

Powyższe wytyczne pokrywają się z klasyfikacją odpadów medycznych (grupa 18 podgrupa 01), zawartą w rozporządzeniu Ministra Środowiska w sprawie katalogu odpadów. Znajdują się tam m.in. narzędzia chirurgiczne i zabiegowe oraz ich resztki, części ciała i organy, pojemniki na krew, inne odpady zawierające żywe drobnoustroje chorobotwórcze lub ich toksyny oraz inne formy zdolne do przeniesienia materiału genetycznego, chemikalia, leki, zużyte kąpiele lecznicze aktywne biologicznie czy pozostałości z żywienia pacjentów oddziałów zakaźnych.

Pojęcie odpadów weterynaryjnych zostało zdefiniowane $\mathrm{w}$ art. 3 ust. 1 pkt 11 u.o., zgodnie z którym są to odpady powstające w związku z badaniem, leczeniem zwierząt lub świadczeniem usług weterynaryjnych, a także w związku z prowadzeniem badań naukowych i doświadczeń na zwierzętach. Do wskazanego rodzaju odpadów należy stosować zatem odpowiednio uwagi poczynione w odniesieniu do odpadów medycznych. Tak więc są to odpady powstałe przy diagnozowaniu, leczeniu i profilaktyce weterynaryjnej tj. odpady zakaźne (padłe zwierzęta), zwierzęta poddane eutanazji, narzędzia chirurgiczne i zabiegowe, wszelkiego rodzaju materiał biologiczny (organy z operacji, narodziny, odpady z laboratoriów patologicznych) oraz określone chemikalia i leki. Odpady weterynaryjne także zostały sklasyfikowane w grupie 18 (02) rozporządzenia Ministra Środowiska w sprawie katalogu odpadów.

Zgodnie $\mathrm{z}$ art. 3 ust. 4 u.o., za odpady niebezpieczne uważa się te, które wykazują co najmniej jedną z właściwości niebezpiecznych. Z kolei załącznik nr 3 do powyższej ustawy 
wskazuje właściwości stanowiące o tym, iż dane odpady należy zaklasyfikować jako niebezpieczne. Są to np. odpady „wybuchowe”, „łatwopalne”, „drażniące”, „toksyczne”, „rakotwórcze”, „zakaźne”, „mutagenne” czy „uczulające”. Załącznik 4 do ustawy o odpadach zawiera wyliczenie składników, które mogą powodować, że odpady są niebezpieczne.

Ustawa o odpadach operuje pojęciami zakaźnych odpadów medycznych oraz zakaźnych odpadów weterynaryjnych. Przez odpady zakaźne należy rozumieć substancje i preparaty zawierające żywe drobnoustroje lub ich toksyny, o których wiadomo lub co do których istnieją wiarygodne podstawy do przyjęcia, że wywołują choroby u ludzi lub innych żywych organizmów.

Reasumując dokonane rozważania, ustawa o odpadach wyróżnia w sposób generalny odpady medyczne i odpady weterynaryjne. Niekiedy mają one charakter zbliżony lub nawet taki sam jak odpady komunalne. Jednakże w obrębie analizowanych rodzajów odpadów pojawiają się podgrupy wymagające klasyfikowania jako odpady niebezpieczne, niekoniecznie zakaźne. Wskazane odpady są niebezpieczne ze względu na swoje właściwości i wymagają również specjalnego, oddzielnego sposobu gospodarowania (np. art. 21 u.o.). Ponadto ustawodawca zdecydował się wyróżnić w obrębie niebezpiecznych odpadów medycznych i niebezpiecznych odpadów weterynaryjnych, szczególne ich podgrupy, które cechują się zakaźnością i objąć je oddzielną regulacją (lex specialis).

\section{GOSPODAROWANIE ZAKAŹNYMI ODPADAMI MEDYCZNYMI I ZAKAŹNYMI ODPADAMI WETERYNARYJNYMI}

Wytwórca jest podmiotem zobowiązanym do gospodarowania wytworzonymi przez siebie odpadami, może on jednak zlecić te obowiązki innym podmiotom, które posiadają specjalne uprawnienia. Według ogólnych reguł odpowiedzialności za gospodarowanie odpadami, w chwili gdy wytwórca lub inny posiadacz odpadów przekaże je następnemu, uprawnionemu 
podmiotowi, odpowiedzialność w przedmiocie gospodarowania odpadami przechodzi na następnego posiadacza odpadów. Jednakże przekazanie odpadów transportującemu nie zwalnia z odpowiedzialności za ich zbieranie lub przetwarzanie, gdyż ustaje ona dopiero $\mathrm{w}$ chwili przejęcia przez następnego posiadacza, który spełnia wskazane w przepisach prawa wymogi.

Odstępstwo od tych generalnych zasad dotyczy zakaźnych odpadów medycznych oraz zakaźnych odpadów weterynaryjnych. W myśl art. 27 ust. 5 u.o., wytwórca takich odpadów jest zwolniony z odpowiedzialności za ich zbieranie lub przetwarzanie dopiero z chwilą dokonania unieszkodliwienia tych odpadów przez następnego posiadacza $\mathrm{w}$ drodze termicznego przekształcenia w spalarni odpadów niebezpiecznych. Przyjęte rozwiązanie wskazuje, że zakaźne odpady medyczne i zakaźne odpady weterynaryjne są rodzajem odpadów, który podlega jak najściślejszej reglamentacji. Ustawodawca zaostrza odpowiedzialność wytwórcy tych odpadów w porównaniu do reguły ogólnej, ponieważ kończy się ona dopiero z chwilą dokonania ich unieszkodliwienia ${ }^{24}$, a nie przejścia na innego posiadacza. Zgodnie z art. 27 ust. 6 u.o. wytwórca może zwolnić się z odpowiedzialności za prawidłowe gospodarowanie omawianymi odpadami, gdy uzyska dokument potwierdzający ich unieszkodliwienie. Jest on wydawany zgodnie z art. 95. ust 4 u.o. przez posiadacza odpadów unieszkodliwiającego zakaźne odpady medyczne i zakaźne weterynaryjne na wniosek wytwórcy. Reguła zawarta w art. 27 ust. 5 u.o. ma także wpływ na ustalenie odpowiedzialnego za czyn z art. $183 \S 3$ Kodeksu Karnego ${ }^{25}$, którego znamieniem ustawowym jest niewłaściwa gospodarka odpadami mogąca zagrozić życiu lub zdrowiu człowieka lub spowodować istotne obniżenie jakości wody, powietrza lub powierzchni ziemi lub zniszczenie w świecie roślinnym lub zwierzęcym w znacznych rozmiarach.

Zgodnie z omówioną wcześniej zasadą bliskości, zakazuje się unieszkodliwiania zakaźnych odpadów medycznych oraz zakaźnych odpadów weterynaryjnych poza obszarem wojewódz- 
twa, na którym zostały wytworzone. Jednocześnie zabroniony jest przywóz takich odpadów do województwa, w którym ich nie wytworzono w celu unieszkodliwienia. Od niniejszej reguły ustawa przewiduje wyjątki w sytuacji, gdy odległość od miejsca wytworzenia do miejsca unieszkodliwienia $\mathrm{w}$ innym województwie jest mniejsza, niż w obrębie tego samego województwa, a także w sytuacji gdy w obrębie województwa, w którym odpady powstały, brak jest odpowiednich instalacji do unieszkodliwiania lub gdy nie mają one wolnych mocy przerobowych. Jeżeli jednak unieszkodliwianie zakaźnych odpadów medycznych lub zakaźnych odpadów weterynaryjnych odbywa się poza obszarem właściwego województwa lub dokonuje się ich przywozu na teren województwa, w którym nie zostały one wytworzone, a nie zachodzą wskazane okoliczności usprawiedliwiające przedmiotowe działania, podmiot taki może ponieść odpowiedzialność karną w postaci kary aresztu lub grzywny (art. 172 u.o.).

Artykuł 23 ust. 1 u.o. wprowadza wymóg selektywnego sposobu zbierania wszelkich odpadów, a ponadto zakaźne odpady medyczne oraz zakaźne odpady weterynaryjne nie mogą być zbierane poza miejscem wytwarzania. Jeżeli występuje konieczność uzasadniona względami bezpieczeństwa lub zapewnienia ciągłości odbioru, marszałek województwa może w drodze decyzji zezwolić na ich zbieranie. W sytuacji, gdy wskazane typy odpadów znajdują się na terenach zamkniętych, przedmiotowe zezwolenie wydaje właściwy regionalny dyrektor ochrony środowiska. Powyższe zezwolenia nie mogą być wydane na dłuższy okres niż rok. Wyjątek od generalnego zakazu zbierania zakaźnych odpadów medycznych oraz zakaźnych odpadów weterynaryjnych dotyczy sytuacji, w których odpady tego rodzaju powstają w związku ze świadczeniem usług medycznych lub weterynaryjnych na wezwanie. Wytwórca takich odpadów jest zobowiązany do bezzwłocznego ich dostarczenia do odpowiednich, przystosowanych pomieszczeń.

Zgodnie z art. 94 ust. 1 u.o. panuje generalny, choć nie bezwzględny, zakaz odzysku odpadów medycznych oraz odpadów weterynaryjnych, chyba że określone ich rodzaje zostaną wskazane w stosownym rozporządzeniu wydanym na podsta- 
wie art. 94 ust. 2 u.o. Wobec powyższego jedyną formą zagospodarowania odpadów medycznych i weterynaryjnych jest ich unieszkodliwienie.

Podmiot odpowiedzialny za unieszkodliwianie omawianych odpadów, zobowiązany jest do prowadzenia tych procesów oraz ich monitoringu, uwzględniając właściwości odpadów, w sposób zgodny ze wskazanymi wymaganiami, które są określone w odpowiednich przepisach. Istotne, dla określenia granic odpowiedzialności takiego podmiotu, jest wyjaśnienie znaczenia słowa „monitoring”, które nie zostało zdefiniowane ustawowo. Zgodnie ze Słownikiem języka polskiego, termin ten oznacza „stałą obserwację i kontrolę jakiś procesów lub zjawisk” bądź „stały nadzór nad jakimś obiektem chronionym”26. Wydaje się, iż jest to zaostrzenie reżimu odpowiedzialności prawnej posiadaczy zakaźnych odpadów medycznych i zakaźnych odpadów weterynaryjnych. Słusznie zauważa K. Karpus, wskazując, iż wskazane zaostrzenie reżimu odpowiedzialności zostało wprost uregulowane tylko w przypadku wytwórcy zakaźnych odpadów medycznych i zakaźnych odpadów weterynaryjnych (art. 27 ust. 5-6 u.o.), a w pozostałych przypadkach nie jest do końca jasne jak powinien wyglądać monitoring procesów unieszkodliwiania tych odpadów ${ }^{27}$.

Na mocy art. 122 ust. 1 pkt 3 u.o. zakaźne odpady medyczne oraz zakaźne odpady weterynaryjne nie mogą być składowane na składowisku odpadów.

Zakaźne odpady medyczne lub zakaźne odpady weterynaryjne unieszkodliwia się przez termiczne przekształcenie w spalarniach odpadów niebezpiecznych (art. 95 ust. 2 u.o.). Powołany przepis używając generalnego terminu „unieszkodliwia się” sugeruje iż jest to jedyny dopuszczalny sposób unieszkodliwiania takich odpadów. Podobny wniosek można wyciągnąć z brzmienia, omówionego wcześniej, art. 27 ust. 5 u.o. zwalniającego z odpowiedzialności za zbieranie lub przetwarzanie zakaźnych

26 Słownik języka polskiego [online], dostęp 13.02.2014, <http://sjp. pwn.pl/slownik/2568296/monitoring>.

27 K. Karpus, op. cit., s. 294. 
odpadów medycznych (weterynaryjnych) ich wytwórcę ${ }^{28}$. Jednakże art. 95 ust. 11 zawiera upoważnienie dla ministra właściwego do spraw zdrowia do wydania rozporządzenia, w którym zostaną m.in. określone dopuszczalne sposoby unieszkodliwiania zakaźnych odpadów medycznych (weterynaryjnych). Mając na uwadze powyższe oraz sugerując się sformułowaniami zawartymi w art. 95 ust. 4 u.o. stwierdzającym, iż posiadacz odpadów, który unieszkodliwia zakaźne odpady medyczne lub zakaźne odpady weterynaryjne w sposób określony w ust. 2 (tj. przez termiczne przekształcenie) oraz art. 95 ust. 12 u.o. określającym warunki, jakimi ma kierować się minister przy wydawaniu rozporządzenia, należy przyjąć, że termiczne przekształcanie nie jest jedyną metodą nieunieszkodliwiana takich odpadów ${ }^{29}$. Definicja terminu „spalarnia odpadów” umieszczona została w art. 3 ust. 1 pkt 26 u.o. Zgodnie z nią jest to zakład lub jego część przeznaczone do termicznego przekształcania odpadów z odzyskiem lub bez odzysku wytwarzanej energii cieplnej, obejmujące instalacje i urządzenia służące do prowadzenia procesu termicznego przekształcania odpadów wraz z oczyszczaniem gazów odlotowych i wprowadzaniem ich do atmosfery, kontrolą, sterowaniem i monitorowaniem procesów oraz instalacjami związanymi z przyjmowaniem, wstępnym przetwarzaniem i magazynowaniem odpadów dostarczonych do termicznego przekształcania oraz instalacjami związanymi z magazynowaniem i przetwarzaniem substancji otrzymanych w wyniku spalania i oczyszczania gazów odlotowych.

Osoba, która poddaje odzyskowi odpady medyczne albo weterynaryjne, gdy odzysk jest niedopuszczalny lub unieszkodliwia wskazane odpady z naruszeniem odpowiednich przepisów, podlega sankcjom karnym w postaci grzywny lub aresztu. Ta sama kara dotyczy osób, które unieszkodliwiają zakaźne

28 Nie wynika to wprost z art. 27 ust. 5 u.o., ale wskazany przepis wymienia tylko jeden sposób zwolnienia z odpowiedzialności za zbieranie (przetwarzanie) zakaźnych odpadów medycznych (weterynaryjnych) tj. przez termiczne ich przekształcenie w spalarni odpadów niebezpiecznych. Zgodnie z wykładnią a contrario stosując inną metodę unieszkodliwiania odpadów, nie można by zwolnić się z odpowiedzialności za przedmiotowe działania.

29 Tak też A. Pacek-Łopalewska, op. cit., s. 290-291. 
odpady medyczne i zakaźne odpady weterynaryjne w drodze współspalania (we współspalarniach). Sankcjom karnym podlega także ten, kto wbrew wskazanym przepisom nie wydaje, nie przekazuje lub nie przechowuje dokumentu potwierdzającego unieszkodliwienie (art. 183 u.o.). Przedmiotowe czyny zabronione $\mathrm{w}$ odniesieniu do odzysku lub unieszkodliwiania odpadów mają charakter powszechny, natomiast wykroczenia polegające na niewydaniu dokumentu potwierdzającego unieszkodliwienie odpadów zakaźnych lub też nieprzekazaniu go wskazanym podmiotom mogą być popełnione tylko przez posiadacza odpadów, który przeprowadził unieszkodliwienie. Z kolei wykroczenia w postaci nieprzechowywania takiego dokumentu mogą być popełnione zarówno przez niego, jak i przez zlecającego unieszkodliwienie wytwórcę odpadów. Powyższe czyny zabronione, poza odzyskiwaniem odpadów medycznych lub weterynaryjnych występującym jedynie w formie umyślności, mogą być popełnione również nieumyślnie ${ }^{30}$.

Zezwolenie na przetwarzanie zakaźnych odpadów medycznych i zakaźnych odpadów weterynaryjnych, polegające na ich unieszkodliwieniu wydaje właściwy organ administracyjny. Przed jej wydaniem, jest on zobowiązany wystąpić do Głównego Inspektora Sanitarnego o zgodę na dopuszczenie do funkcjonowania instalacji lub urządzenia do tych odpadów. Przedmiotowa zgoda zawiera szereg wymogów technicznych i formalnych, które muszą zostać spełnione. Są to m.in. rodzaj i model urządzenia lub instalacji, dokładne parametry procesów prowadzących do unieszkodliwiania, wymagania związane z kontrolą tych procesów, a także masę unieszkodliwionych odpadów w okresie roku. Istotne jest, że w omawianej sytuacji nie mamy do czynienia ze współdziałaniem organów administracji w myśl art. 106 kodeksu postępowania administracyjnego $^{31} \mathrm{z}$ uwagi na fakt, iż akt (zgoda) wydawany przez Głównego Inspektora Sanitarnego nosi znamiona decyzji administracyjnej, która w jednoznaczny sposób określa obowiązki posiadacza odpadów w kwestii dopuszczenia do funkcjonowania instalacji lub

31 Tj. Dz.U. z 2013 r., poz. 267 ze zm. 
urządzenia do unieszkodliwiania tego rodzaju odpadów. Wobec powyższego, organ właściwy do wydania zezwolenia jest w pełni związany aktem nazwanym „zgodą” wydanym przez Głównego Inspektora Sanitarnego ${ }^{32}$.

Odpady medyczne i weterynaryjne nieposiadające cech zakaźnych, mogą być sklasyfikowane jako niebezpieczne z racji posiadania innych cech pozwalających dokonać takiego zaszeregowania i wówczas podlegają reżimowi postępowania właściwemu dla odpadów niebezpiecznych (np. art. 21 u.o.). Polega on m.in. na specjalnych regulacjach w przedmiocie mieszania odpadów, zmiany klasyfikacji, szczególnych warunków zbierania czy ewidencji.

\section{SPOSOBY UNIESZKODLIWIANIA ODPADÓW MEDYCZNYCH I WETERYNARYJNYCH}

Unieszkodliwianie odpadów medycznych oraz weterynaryjnych, niezależnie od użytej metody musi spełniać określone wymogi, które gwarantują skuteczność całego procesu. Najkorzystniej i najbezpieczniej jest, gdy następują one w trakcie jednego procesu. Są to ${ }^{33}$ :

- likwidacja zagrożenia infekcyjnego,

- neutralizacja niebezpiecznych związków chemicznych (np. pochodzących z lekarstw bądź odczynników chemicznych),

- spopielenie odpadów zawierających tkankę uniemożliwiające identyfikowanie pozostałości w kształcie.

Zgodnie z art. 250 ust. 1 ustawy o odpadach z 2012 r., przepisy wykonawcze wydane na podstawie niektórych przepisów ustawy z dnia 27 kwietnia 2001 r. o takim samym tytule ${ }^{34}$,

32 K. Karpus, op. cit., s. 298-299.

33 Z. Grabowski, G. Wielgosiński, „Odpady medyczne i weterynaryjne warunki unieszkodliwiania" [online], dostęp: 12.04.2014, <http://www. mos.gov.pl/g2/big/2009_07/5acf65722546992127050452baea2828.pdf $>$.

34 Tj. Dz.U. z 2010 r. Nr 185, poz. 1243 ze zm. 
zachowują moc do czasu wejścia w życie przepisów wykonawczych wydanych na podstawie ustawy o odpadach z 2012 r., ale nie dłużej niż przez okres 24 miesięcy od wejścia w życie ustawy z 2012 r. Jednym z takich obowiązujących aktów normatywnych jest rozporządzenie Ministra Zdrowia z dnia 23 grudnia 2002 r. w sprawie dopuszczalnych sposobów i warunków unieszkodliwiania odpadów medycznych i weterynaryjnych ${ }^{35}$. Nie jest to sytuacja właściwa z uwagi na zasady techniki prawodawczej, niemniej nie ma ona istotnego wpływu na całość uregulowań w omawianych kwestiach.

Na mocy §1 ust. 1 powołanego wyżej rozporządzenia, odpady medyczne i weterynaryjne mogą być unieszkodliwiane w sposób termiczny polegający m.in. na spaleniu odpadów w drodze ich utlenienia (w instalacjach lub urządzeniach zlokalizowanych na lądzie), przez autoklawowanie, w drodze dezynfekcji termicznej, działania mikrofal lub inną obróbkę fizyczno chemiczną. Możliwe jest łączenie wskazanych metod.

Spalanie jest najpowszechniejszą oraz najczęstszą metodą unieszkodliwiania odpadów, w tym odpadów medycznych oraz weterynaryjnych. Polega ono na istotnej przebudowie struktury odpadu kończącej się na procesie jego spopielenia ${ }^{36}$. Aby możliwie najbardziej ograniczyć wpływ omawianych procesów unieszkodliwiania na środowisko, konieczne są działania związane z właściwą segregacją odpadów medycznych i weterynaryjnych, gdyż często stanowią one mieszankę różnego rodzaju odpadów, tj. zainfekowane biologicznie przedmioty, odpady biologiczne, chemikalia (odczynniki, leki) oraz zwykłe odpady komunalne. $\mathrm{Z}$ tego powodu należy pamiętać, że odpady zainfekowane (zakaźne) stanowią jedynie 10\% ogólnej masy odpadów szpitalnych, a obecność tworzyw sztucznych powoduje, że w czasie spalania do atmosfery wydostają się bardzo szkodliwe dla środowiska opary metali ciężkich, opary plastików zawierające chlor oraz opary innych materiałów i tworzyw. Dodatkowo, w wysokiej temperaturze palone substancje reagują wzajemnie 
ze sobą i prowadzą do powstania nowych związków chemicznych, często bardziej szkodliwych niż pierwotne odpady ${ }^{37}$.

Sanitacja parowa dokonywana jest za pomocą autoklawu (sterylizator parowy) polega na umieszczeniu odpadów w komorach ciśnieniowych nasyconych parą wodną. Metoda ta cechuje się wysoką skutecznością wyjaławiania w stosunku do wszystkich drobnoustrojów chorobotwórczych. Instalacje służące do sanitacji parowej są znacznie tańsze w budowie oraz eksploatacji (niski koszt jednostkowy procesu) niż systemy przekształcania termicznego, a ponadto nie powodują przenikania do atmosfery szkodliwych substancji. W efekcie omawianych czynności następuje redukcja odpadów do 75\%. Pozostałości po tym procesie mają cechy odpadów komunalnych. Wskazaną metodę zazwyczaj wykorzystuje się w ośrodkach medycznych do sterylizacji przedmiotów wielokrotnego użytku.

Dezynfekcja termiczna (sucha) składa się z dwóch etapów. Pierwszy etap polega na wstępnym rozdrobnieniu odpadu do średnicy około $25 \mathrm{~mm}$, natomiast drugi etap stanowi jego podgrzanie w specjalnym urządzeniu. Cały proces trwa około 20 minut, a w jego trakcie temperatura waha się od 110 do $140^{\circ} \mathrm{C}$. Wynikiem zastosowania tej metody jest $80 \%$ redukcja objętości odpadu i 20-35\% utrata jego masy. Dezynfekcja termiczna sprawdza się przy unieszkodliwianiu odpadów infekcyjnych oraz przedmiotów ostrych. Z kolei nie powinna być stosowana w przypadku odpadów patologicznych czy materiałów niskoradioaktywnych ${ }^{38}$.

Sanitacja mikrofalowa pomimo iż należy do technologii stosunkowo nowych, jest już wykorzystywana w wielu krajach. Składa się z kilku etapów. Pierwszy polega na czyszczeniu parą odpadów medycznych, następnie są one kruszone mechanicznie, a po takim przygotowaniu trafiają do wcześniej podgrzanej komory w celu poddania ich, przynajmniej przez 30 minut, promieniowaniu mikrofalowemu. Na koniec odpady przetrzymuje się w temperaturze co najmniej $95^{\circ} \mathrm{C}$, aby zapewnić ostateczną

37 P. Głuszczyński, „Małe ale równie niebezpieczne” [online], dostęp: 09.02.2014, <http://zb.eco.pl/inne/spalarni/med.htm>.

38 H. Wyrębek, op. cit., s. 126. 
dezynfekcję. W trakcie stosowania sanitacji mikrofalowej objętość odpadów zmniejsza się o około 80\% i bez przeszkód mogą one trafić na zwykłe, komunalne składowisko. Charakterystyczny dla sanitacji mikrofalowej jest fakt, iż ogrzewanie mikrofalowe działa wewnętrznie, a nie zewnętrznie, co umożliwia lepszą penetrację ciepła i pary. Podczas używania tej metody nie ma żadnych emisji szkodliwych substancji ${ }^{39}$.

W celu unieszkodliwienia odpadów medycznych oraz weterynaryjnych można stosować także hydroklaw. Jest to urządzenie wykorzystujące hydrolizę organicznych składników odpadów, która przebiega pod wpływem dynamicznego działania pary i temperatury. Wewnątrz hydroklawu znajduje się mieszająco-rozdrabniający mechanizm obrotowy. Wprowadzenie pary połączone jest $\mathrm{z}$ natychmiastowym podgrzaniem $\left(152,7^{\circ} \mathrm{C}\right)$ mieszanych odpadów i ich odwodnieniem (do $\left.40 \%\right)$. Skondensowana para jest zawracana do procesu, a wielkość załadunku nie ma wpływu na skuteczność wyjaławiania. Zastosowanie przedstawianej metody trwa około godziny i prowadzi do około $50 \%$ redukcji masy odpadów oraz około $80 \%$ redukcji ich objętości ${ }^{40}$.

Znanym od wieków sposobem usuwania odpadów medycznych oraz weterynaryjnych, zwłaszcza patologicznych, jest ich grzebanie w ziemi. Obecnie metoda ta stanowić może doraźne rozwiązanie w przypadku wystąpienia wyjątkowych zdarzeń (np. klęski żywiołowe, katastrofy czy konflikty zbrojne), zwłaszcza jeżeli wytwórca wskazanych odpadów nie ma możliwości skorzystania z innych metod unieszkodliwiania. Odpady infekcyjne, uprzednio odpowiednio zabezpieczone, powinny być składowane w wydzielonym miejscu, na zasadach porównywalnych ze składowaniem. Warstwa ziemi zapobiega odorom, ogranicza dostęp gryzoni oraz rozwój insektów. Grzebanie jest stosunkowo tanie oraz skuteczne, jeżeli zachowa się odpo-

39 J. Wandrasz, Gospodarka odpadami medycznymi, Poznań 2000, s. 46.

40 Państwowa Inspekcja Sanitarna, „Wybrane Metody i Technologie Utylizacji Odpadów Medycznych" [online], dostęp: 10.02.2014, <http://pis.msw.gov. pl/is/materialy-szkoleniowe/higiena-srodowiska/1069, Metody-utylizacji-odpadow.html>. 
wiednie warunki składowania, tj. ograniczony dostęp do miejsca grzebania, wyłożenie go warstwą nieprzepuszczalną, która zapobiega przedostawaniu się odcieków do wód gruntowych, a składowane odpady jednorazowo nie zawierają zbyt dużej ilości odpadów chemicznych ${ }^{41}$.

Do innych metod unieszkodliwiania należą: dezynfekcja chemiczna (np. przy zastosowaniu aldehydów, związków chloru, związków fenoli), mineralizacja odpadów przez wymieszanie odpadów (zwłaszcza farmaceutyków) z cementem oraz innymi substancjami zestalającymi czy metoda sterylizacji z mineralizacją, która polega na rozdrobnieniu, sterylizacji, a następnie poddaniu działaniu określonych substancji i ustabilizowaniu wszystkiego cementem.

W Polsce najpopularniejszą metodą unieszkodliwiania odpadów medycznych i weterynaryjnych jest ich spalanie (około 69\% w 2006 r.). Ilość spalarni, zwłaszcza z uwagi na zamykanie tych przestarzałych i niespełniających wymogów emisyjnych znacząco spadła. Ponadto obserwuje się wzrost znaczenia alternatywnych metod unieszkodliwiania analizowanych typów odpadów (m.in. autoklawowanie, dezynfekcja termiczna czy sanitacja mikrofalowa) ${ }^{42}$.

Wskazanie dopuszczalnych sposobów unieszkodliwiania w odniesieniu do konkretnych odpadów medycznych i weterynaryjnych zawarte zostało w załączniku nr 1 do rozporządzenia Ministra Zdrowia z dnia 23 grudnia 2002 r. w sprawie dopuszczalnych sposobów i warunków unieszkodliwiania odpadów medycznych i weterynaryjnych.

\section{PLAN GOSPODARKI ODPADAMI}

Krajowy plan gospodarki odpadami stanowi załącznik do uchwały Rady Ministrów z dnia 24 grudnia 2010 r. w sprawie

41 Ibidem.

42 Z. Grabowski, G. Wielgosiński, op. cit. 
„Krajowego planu gospodarki odpadami”43. W rozdziale 2.2 dotyczącym analizy stanu gospodarki odpadami niebezpiecznymi znajduje się część poświęcona odpadom medycznym i weterynaryjnym. Zgodnie $\mathrm{z}$ nią $\mathrm{w}$ większości placówek medycznych i weterynaryjnych stosuje się selektywne zbieranie odpadów do specjalnych pojemników lub worków. Zakaźne odpady medyczne i zakaźne odpady weterynaryjne są unieszkodliwiane przez przekształcanie termiczne. W 2009 r. funkcjonowało 45 spalarni takich odpadów, które w pełni zaspokajały potrzeby kraju w analizowanej kwestii. Wskazano jednak, iż problem stanowi ich nierównomierne rozmieszczenie na poziomie wojewódzkim, co nie gwarantuje w pełni przestrzegania zasady bliskości.

Ilość odpadów stricte medycznych, wytworzonych w 2008 r. wynosiła 35,5 tys. ton, a odpady niebezpieczne (w tym zakaźne) stanowiły 29, 394 tys. ton. W przeliczeniu na jednego mieszkańca w 2008 r. zostało wytworzonych 0,93 kg odpadów z grupy 18 01, czyli powstałych w wyniku diagnozowania, leczenia i profilaktyki medycznej. Ilość odpadów weterynaryjnych wytworzonych w 2008 r. wynosiła 0,42 tys. ton.

Ponadto stwierdzono niską wiarygodność klasyfikacji odpadów wytworzonych na terenach placówek służby zdrowia i placówek weterynaryjnych, wskutek klasyfikowania odpadów z grupy 180104 (jest to pojęcie zbiorcze, które dotyczy odpadów medycznych innych niż niebezpieczne, niesklasyfikowanych wcześniej w obrębie grupy 18) jako odpady komunalne.

\section{ZAKOŃCZENIE}

Celem niniejszego opracowania jest scharakteryzowanie oraz wskazanie procedur gospodarowania odpadami medycznymi i weterynaryjnymi. Analizowane typy odpadów, wbrew powszechnym opiniom, nie tworzą grup jednorodnych. Ważny jest fakt, zgodnie z którym tylko niewielką ich część (10-15\%) 
stanowią odpady o właściwościach zakaźnych. Dodatkowo, odpady medyczne i weterynaryjne mogą być uznane za niebezpieczne, ponieważ posiadają inne, niż zakaźne, cechy. Wobec tego należy wskazać, że łączna liczba wszystkich odpadów wymagających specjalnego traktowania to około 20-25\% sumy odpadów medycznych i weterynaryjnych. Zdarza się również, iż omawiane rodzaje odpadów, nawet posiadające właściwości niebezpieczne (zakaźne), wywołują mniejsze zagrożenie dla środowiska i człowieka niż niektóre odpady o charakterze komunalnym lub komunalnopodobnym.

Problematyka gospodarowania odpadami medycznymi i weterynaryjnymi stanowi ważny przedmiot zainteresowania całego społeczeństwa. Ludzie traktują je z dużą rezerwą, która spowodowana jest obawami o stan swojego zdrowia czy środowiska. Dlatego są najczęściej niechętni przedsięwzięciom mającym na celu budowę spalarni. Takie instalacje nie cieszą się aprobatą społeczności lokalnych, chociaż wskazuje się, iż przy zachowaniu właściwych technologii są one bezpieczne i przyjazne dla środowiska.

Ustawa o odpadach z 2012 r szeroko implementuje prawo Unii Europejskiej realizując wspólne cele w przedmiocie gospodarowania odpadami oraz ochrony środowiska.

\section{BIBLIOGRAFIA}

Forowicz K., Odpady Szpitalne - bać się czy nie?, „Odpady i Środowisko" 2012, nr 1.

Głuszczyński P., „Mate ale równie niebezpieczne” [online], dostęp: 09.02.2014, <http://zb.eco.pl/inne/spalarni/med.htm>.

Grabowski Z., Wielgosiński G., „Odpady medyczne i weterynaryjne - warunki unieszkodliwiania" [online], dostęp: 12.04.2014, <http://www.mos.gov.pl/g2/big/2009_07/5acf65722546992127050452baea2828.pdf $>$.

Kowalska M., Praktyczna klasyfikacja odpadów powstających $w$ placówkach stużby zdrowia. Gospodarka odpadami medycznymi, Kraków 2002.

Najwyższa Izba Kontroli, Departament Środowiska, Rolnictwa i Zagospodarowania Przestrzennego, Informacja o wynikach kontroli postępowania z odpadami medycznymi, Warszawa 2007. 
Pacek-Łopalewska A., Ustawa o odpadach. Komentarz, Wrocław 2013. Paczuski R., Prawo ochrony środowiska, Bydgoszcz 2000.

Państwowa Inspekcja Sanitarna, „Wybrane Metody i Technologie Utylizacji Odpadów Medycznych" [online], dostęp: 10.02.2014, <http://pis.msw.gov.pl/is/materialy-szkoleniowe/higiena-srodowiska/1069,Metody-utylizacji-odpadow.html>.

Radecki W., Ustawa o odpadach. Komentarz, Warszawa 2013.

Rakoczy B. (red.), Ustawa o odpadach. Komentarz, Warszawa 2013.

Wandrasz J., Gospodarka odpadami medycznymi, Poznań 2000.

Wierzbowski B., Rakoczy B., Prawo ochrony środowiska. Zagadnienia podstawowe, Warszawa 2012.

Wladarz M., Gospodarka odpadami. Poradnik przedsiębiorcy, Warszawa 2003.

Wyrębek H., Zarządzanie gospodarka odpadami medycznymi w Polsce, „Zeszyty Naukowe Uniwersytetu Przyrodniczo-Humanistycznego w Siedlcach. Seria: Administracja i Zarządzanie" 2010, nr 87.

Kontakt e-mail:

marszelewski@gmail.com 